John Carroll University

Carroll Collected

Biology

$8-2016$

\title{
Phenotypic plasticity and population
} differentiation in response to salinity in the invasive cordgrass Spartina densiflora

Rebecca E. Drenovsky

John Carroll University, rdrenovsky@jcu.edu

Brenda J. Grewell

University of California, Davis

Jesus M. Castillo

Universidad de Sevilla

Meghan J. Skaer Thomason

University of California, Davis

Follow this and additional works at: http:// collected.jcu.edu/biol-facpub

Part of the Biology Commons

\section{Recommended Citation}

Drenovsky, Rebecca E.; Grewell, Brenda J.; Castillo, Jesus M.; and Skaer Thomason, Meghan J., "Phenotypic plasticity and population differentiation in response to salinity in the invasive cordgrass Spartina densiflora" (2016). Biology. 10.

http://collected.jcu.edu/biol-facpub/10 


\title{
Phenotypic plasticity and population differentiation in response to salinity in the invasive cordgrass Spartina densiflora
}

\author{
Brenda J. Grewell · Jesús M. Castillo • \\ Meghan J. Skaer Thomason • \\ Rebecca E. Drenovsky
}

\begin{abstract}
Salinity and tidal inundation induce physiological stress in vascular plant species and influence their distribution and productivity in estuarine wetlands. Climate change-induced sea level rise may magnify these abiotic stressors and the physiological stresses they can cause. Understanding the potential of invasive plants to respond to predicted salinity increases will elucidate their potential niche breadth. To examine potential phenotypic plasticity and functional trait responses to salinity stress in the invasive cordgrass Spartina densiflora, we collected rhizomes from four invasive populations occurring from
\end{abstract}

Guest editors: Alan Gray and Malika Ainouche/Invasive Spartina.

Electronic supplementary material The online version of this article (doi:10.1007/s10530-015-1041-x) contains supplementary material, which is available to authorized users.

B. J. Grewell $(\varangle) \cdot$ M. J. Skaer Thomason

USDA-ARS Exotic and Invasive Weeds Research Unit,

Department of Plant Sciences, University of California,

Davis, CA 95616, USA

e-mail: bjgrewell@ucdavis.edu;

brenda.grewell@ars.usda.gov

J. M. Castillo

Departamento de Biología Vegetal y Ecología,

Universidad de Sevilla, 1095 Apartado, Spain

R. E. Drenovsky

Biology Department, John Carroll University, University Heights, OH 44118-4581, USA
California to Vancouver Island, British Columbia on the Pacific Coast of North America. In a glasshouse common garden experiment, we measured plant traits associated with growth and allocation, photosynthesis, leaf pigments, and leaf chemistry and calculated plasticity indices across imposed salinity treatments. Fifteen of 21 leaf chemistry, pigment, morphological and physiological traits expressed plastic responses to salinity. When averaged across all measured traits, degree of plasticity did not vary among sampled populations. However, differences in plasticity among populations in response to salinity were observed for 9 of 21 measured plant traits. Leaf chemistry and adaxial leaf rolling trait responses demonstrated the highest degree of plasticity, while growth and allocation measures were less plastic. Phenotypic plasticity of leaf functional traits to salinity indicates the potential of $S$. densiflora to maintain invasive growth in response to rising estuarine salinity with climate change.

Keywords Invasive species - Phenotypic plasticity · Plant invasions · Plant functional traits · Halophyte . Sea level rise

\section{Introduction}

Global change and biological invasions are likely synergistic processes that interact and impart negative ecological and economic impacts (Vilà et al. 2007). 
Invasive plant species have successfully colonized and spread in dynamic environments quite different from their native range and may therefore have traits that confer invasion success in changing environments (Dukes and Mooney 1999). Estuarine wetlands are highly variable environments that induce physiological stress near tolerance limits of many vascular plant species (Adam 1993). Spatially and temporally dynamic salinity and tidal inundation regimes interact to control soil water potential and induce biochemical and physiological responses in plant species, greatly influencing their growth, biological interactions, distribution and productivity (Howard and Mendelssohn 1999). Estuarine plants also face rising sea level, increases in ranges of aqueous salinity regimes, and variations in other influential abiotic processes affected by global climate change that can dramatically alter plant community and ecosystem processes (Parker et al. 2011). Interspecific variation in salinity acclimation among dominant species in these communities is an important driver of both landscape-scale vegetation zonation and small-scale vegetation pattern in salt marshes (Bertness 1991; Shumway and Bertness 1994) and therefore has the potential to influence species invasiveness in these habitats.

As environments change, some introduced species can rapidly evolve by adapting via genetic differentiation in response to local selection pressures (Leger and Rice 2003; Maron et al. 2004), genetic drift or mutation (Dlugosch and Parker 2008) or epigenetic processes (Richards 2012). Genetic variation and/or novel genotypes resulting from intra- or interspecific hybridization also may facilitate rapid evolution of invasive plants (Strong and Ayres 2013). By increasing niche breadth in spatially heterogeneous environments, phenotypic plasticity may be a contributing adaptive mechanism, conveying fitness benefits to individual plants and promoting invasiveness (Richards et al. 2006; Caño et al. 2008; Drenovsky et al. 2012). Given the cascading influences of dominant invaders on critical ecological processes, improved knowledge of their functional traits may help us understand their capacity to adjust to environmental changes and thereby support their persistence and spread (Hester et al. 2001).

Globally, several species of Spartina (cordgrasses) are highly successful invaders in estuarine wetlands where they significantly change the physical structure, reduce the biological diversity and affect the ecological function of tidal marshes and mudflats (Thompson 1991; Ayres et al. 2004; Ainouche et al. 2009; Strong and Ayres 2013). The austral cordgrass, Spartina densiflora Brongn. (Poaceae) is native to the southern Atlantic coast of South America (Fortune et al. 2008). It was first introduced to Chile, followed by accidental introductions to Gulf of Cádiz, southeast Spain in the sixteenth century (Castillo et al. 2010) and to Humboldt Bay, California in the mid-nineteenth century (Spicher and Josselyn 1985) coincident with intercontinental shipping of lumber and other products (Nieva et al. 2005; Bortolus 2006; Fortune et al. 2008). In 1977, S. densiflora was intentionally introduced to San Francisco Bay to stabilized tidal creek banks in a wetland restoration project (Faber 2000). In recent decades populations have spread in both Spain and California, and multiple introductions are unknown but possible. It is a heptaploid species (Ayres et al. 2008) thought to be a product of reticulate evolution by an ancient interspecific hybridization in its native South American range (Fortune et al. 2008; Ainouche et al. 2012). Molecular markers suggest genetic diversity among populations in the native range (Fortune et al. 2008). Genetic analyses of samples from San Francisco Bay, Humboldt Bay and Mad River California were genetically similar to each other (Ayres et al. 2008) and to a population in Chile (Fortune et al. 2008).

High sexual reproduction and vegetative growth via tillering play a role in establishment and spread of $S$. densiflora populations (Kittelson and Boyd 1997), producing dense, large tussocks through "phalanx" (centrifugal and multidirectional) clonal growth (Nieva et al. 2005). High belowground biomass production occurs via roots and rhizomes (Perazzolo and Pinheiro 1991; Nieva et al. 2001). Populations have colonized a range of substrate types including mud flats to sandy or cobble beaches within estuaries (Bortolus 2006), yet growth of the species in the native range is greatly dependent on tidal regimes and resultant substrate conditions in intertidal habitat (Di Bella et al. 2014). In Spain, invasive populations of $S$. densiflora tolerate high salinity, but expansion and colonization rates are highest in brackish wetlands influenced by freshwater outflow (Castillo et al. 2005). The recent northward expansion of $S$. densiflora across a $12^{\circ}$ latitudinal gradient along the Pacific coast of the United States (USA) and Canada provides an opportunity to investigate how invasive vascular plants establish in novel environments and succeed across 
steep estuarine salinity gradients. These dynamic estuaries experience high seasonal and annual variability in precipitation and freshwater river inflow.

Using a glasshouse common garden experiment, we evaluated the short-term performance of four invasive $S$. densiflora populations differing in latitude and salinity conditions to examine potential variation in salinity stress. Specifically, we evaluated functional traits and their plasticity in response to salinity $(0.5,15$ and $35 \mathrm{ppt}$ ). Our overall objective was to assess whether trait responses to salinity gradients were dependent on population differentiation or phenotypic plasticity or a combination of both factors. We hypothesized that (1) $S$. densiflora would show a high phenotypic plasticity in response to contrasted salinities, based on previous field observations (Castillo et al. 2014); and (2) interpopulation differences in response to salinity may exist.

\section{Methods}

Source populations, collection and propagation techniques

We collected $S$. densiflora plants in summer 2010 from four estuaries distributed latitudinally along the Pacific west coast of North America, including: (1) San Francisco Estuary (SF), California $\left(37^{\circ} 56^{\prime} 33^{\prime \prime} \mathrm{N}\right.$, $122^{\circ} 30^{\prime} 55^{\prime \prime} \mathrm{W}$ ); (2) Humboldt Bay Estuary (HB), California $\left(40^{\circ} 49^{\prime} 53^{\prime \prime} \mathrm{N}, 124^{\circ} 10^{\prime} 17^{\prime \prime} \mathrm{W}\right)$; (3) $\mathrm{Mad}$ River Estuary (MR), California $\left(40^{\circ} 56^{\prime} 10^{\prime \prime} \mathrm{N}\right.$, $124^{\circ} 7^{\prime} 48^{\prime \prime} \mathrm{W}$ ); and Baynes Sound (VI, Vancouver Island), British Columbia $\left(49^{\circ} 33^{\prime \prime} \mathrm{N}, 124^{\circ} 52^{\prime} 09^{\prime \prime} \mathrm{W}\right)$. The four estuaries experience mesotidal ranges and mixed semidiurnal tidal cycles each lunar day (24.84 h) with lowest tidal elevations occurring during daylight during the period of summer growth (Callaway et al. 2012). Estuarine salinity varies seasonally and annually, ranging from oligohaline (0.5-5.0 ppt) to euhaline ( $>30 \mathrm{ppt}$ ) conditions. Soils were sampled from population sites during low tides. Ten sediment cores ( $5 \mathrm{~cm}$ diameter, $0-10 \mathrm{~cm}$ depth) were randomly collected from habitat of each study population, stored in sealed containers and transported to the laboratory. A subsample of the sediment was mixed in a 1:1 ratio with distilled water to determine electrical conductivity (Hanna Instruments Model 9033, Woonsocket, Rhode Island, USA). Sediment salinity measured as electrical conductivity of soil solutions at the collection sites during summer growing season were brackish, ranging from oligohaline $\left(0.2 \mathrm{mS} \mathrm{cm}{ }^{-1}\right.$; MR) to polyhaline levels $\left(8.8 \pm 0.9 \mathrm{mS} \mathrm{cm}^{-1}\right.$ (VI), $11.9 \pm$ $0.2 \mathrm{mS} \mathrm{cm}^{-1}(\mathrm{HB})$, and $13.8 \pm 0.7 \mathrm{mS} \mathrm{cm}^{-1}(\mathrm{SF})$.

Ten adult tussocks of $S$. densiflora with between 10 and 80 live shoots (ca. 2-3 years old) from each study population were randomly selected. Low genetic variation of S. densiflora (Ayres et al. 2008) should ensure that collected individuals were representative of the population. Rhizomes were separated from the plants and transported on ice to Davis, California. Clean rhizomes from each plant were separated and weighed, and 1-3 rhizome fragments per plant were used to standardize initial mass of rhizomes transplanted into pots with drainage holes $(15 \mathrm{~cm}$ diameter $\times 17.5 \mathrm{~cm}$ height, Nursery Supplies, Inc.) filled with expanded perlite substrate (Therm-O-Rock West, Inc.). Potted rhizomes were placed in 180-1 aquatic mesocosms filled with fresh water to $10 \mathrm{~cm}$ below perlite surface for sub-irrigation, and grown for 5 months in a glasshouse at Davis, California to establish tussocks for experimental use.

\section{Experimental design}

Following tussock propagation, experimental plants were exposed to experimental salinity treatments created using $20 \%$ modified Hoagland's solution and Hoagland's solution plus sea salts (Instant Ocean $^{\circledR}$, Aquarium Systems Inc., Mentor, Ohio USA) to achieve desired concentrations; solutions were refreshed weekly. Experimental plants were subjected to freshwater (0.5 ppt) and brackish (15 ppt) treatments in mesocosms for 2 weeks. One brackish mesocosm was then increased to marine salinity (35 ppt) level for an additional 2 weeks of conditioning. After salinity conditioning, plants were randomized into the experimental design using fifteen 84-1 plastic mesocosms $(0.53-\mathrm{m}$ long $\times 0.53-\mathrm{m}$ wide $\times 0.30-\mathrm{m}$ deep). Treatments were randomly assigned within a nested, full factorial design (4 populations $\times 3$ salinity levels $\times 5$ replicates). Five potted tussocks (replicates) from each of the four population sites were randomly assigned to one of three aqueous salinity treatments representing the potential range of exposure in invaded estuaries for a total of 60 experimental plants. Replicates from each of four sites were randomly nested within each of the 15 mesocosms. 
Water level in each mesocosm was maintained at $10 \mathrm{~cm}$ below substrate surface throughout the experiment. The experimental treatments were imposed for 30 days (March 8-April 6, 2011) in a glasshouse with controlled temperature between 21 and $25{ }^{\circ} \mathrm{C}$ and a $15 \mathrm{~h}$ daily photoperiod was imposed with high intensity discharge (HID) lights (GE Lucalox LU1000/ ECO HPS $1000 \mathrm{~W}$ ).

Plant growth and foliar responses

The following plant traits were measured: shoot and root biomass, root mass ratio, leaf morphology, leaf area, leaf elongation rate, leaf gas exchange, leaf water potential, fluorescence traits, photosynthetic pigment concentrations, free proline accumulation, glycinebetaine concentration, leaf $\mathrm{N}$ concentration, leaf $\mathrm{Na}$ concentration, and salt exudation rates. Shoot biomass (SM; g) and root biomass (included all subsurface biomass, RM; g) were measured for each tussock after samples were ovendried at $70{ }^{\circ} \mathrm{C}$ for $48 \mathrm{~h}$, and root mass ratio (RMR) was calculated as root plus rhizome biomass divided by total biomass. Each tussock was photographed and total leaf area $\left(\mathrm{LA} ; \mathrm{m}^{2}\right)$ was calculated using WinFOLIA (Regent Instruments Inc., Saint-Foy, Quebec, Canada). For calculations of specific leaf area (SLA; $\mathrm{m}^{2} \mathrm{~g}^{-1}$ ), leaf mass (LM) was determined from $0.5 \mathrm{~cm}$ diameter drilled samples from five random flag leaf samples per plant. Specific leaf area was then calculated as LA/LM of the leaf disks. Apical leaf elongation (growth) rate and adaxial leaf rolling were measured and calculated per Castillo et al. (2014).

Measurements of net photosynthetic rate $\left(\mathrm{A}_{\mathrm{sat}}\right)$, stomatal conductance $\left(\mathrm{g}_{\mathrm{s}}\right)$, and light- and dark-adapted fluorescence over the same leaf area were carried out on days 21-26. For each replicate tussock, measurements were made on the second-youngest, fully expanded leaf from each of five randomly selected tillers using a LI-COR 6400 portable infrared $\mathrm{CO}_{2}$ analyzer (LI-COR Biosciences, Lincoln, NE, USA) in differential mode and in an open circuit coupled to a pulse-amplitude modulated (PAM) fluorimeter. Photosynthetic photon flux density inside the chamber was maintained at $1000 \mu \mathrm{mol} \mathrm{m} \mathrm{m}^{-2} \mathrm{~s}^{-1}$, with the LI-6400 LCF actinic light source (90\% red, $10 \%$ blue), $400 \mu \mathrm{mol} \mathrm{mol}{ }^{-1} \mathrm{CO}_{2}$ concentration, and flow rate set to $400 \mu \mathrm{mol} \mathrm{s}^{-1}$. Light-adapted measures were conducted on sunny days within $2 \mathrm{~h}$ of solar noon. Before measurement, leaves were rinsed with deionized water to remove salts that had accumulated on the leaf surfaces and allowed to dry. Each individual gas exchange measurement consisted of three values logged at $10 \mathrm{~s}$ intervals once stable conditions were achieved inside the chamber. Then, measured leaf sections were marked and dark-adapted fluorescence measures were taken on the same leaf sections at night (pre-dawn, 0330-0515 h), avoiding illumination of the leaves while taking measurements. The marked leaf sections were harvested to determine leaf area. Simultaneous measurement of photosynthesis and stomatal conductance allowed us to calculate intrinsic water use efficiency (carbon fixed/water lost) of experimental plants (WUE; mmol $\mathrm{CO}_{2} \mathrm{~mol} \mathrm{H}_{2} \mathrm{O}^{-1}$ ). For each replicate tussock, leaf water potential ( $\left.\Psi_{\text {leaf }}\right)$ was measured on five randomly selected tillers with a Scholander pressure bomb within $2 \mathrm{~h}$ of solar noon on days 23-27 on fully expanded adult leaves exposed to direct sunlight.

Approximately $2 \mathrm{~g}$ of fresh tissue were collected from young fully mature leaves and frozen for analysis of proline and photosynthetic pigments. Leaf, stem, and root tissues were collected separately and dried at $70{ }^{\circ} \mathrm{C}$ and weighed. Dry leaf tissue was ground to pass through a No. 40 mesh screen for nitrogen $(\mathrm{N})$, sodium $(\mathrm{Na})$, and glycinebetaine analysis. Leaf $\mathrm{N}$ concentration was determined using a CHNS/O analyzer (Perkin Elmer 2400, Waltham, MA, USA). Leaf $\mathrm{Na}$ was measured with a sodium electrode on dry-ashed samples that were dissolved in $1 \mathrm{M} \mathrm{HCl}$. Proline concentration in leaf samples was determined (following the protocol in Bates et al. 1973), and glycinebetaine was estimated as quaternary ammonium compounds (following the protocol in Grieve and Grattan 1983). Photosynthetic pigments were extracted in $80 \%$ aqueous acetone, with chlorophyll $a(\mathrm{Chl} a)$, chlorophyll $b(\mathrm{Chl} b)$ and carotenoids $\left(\mathrm{C}_{\mathrm{x}+\mathrm{c}}\right)$ concentrations determined with a spectrophotometer (Beckman DU-64, Beckman Coulter, Inc., Brea, CA, USA). Leaf sodium exudation rates were measured on the youngest, fully developed leaves (following the protocol in Christman et al. 2009).

\section{Plasticity assessment}

Phenotypic plasticity indices were calculated for each population and plant trait to evaluate differences in phenotypic trait expression (Valladares et al. 2006; 
Molina-Montenegro and Naya 2012). The phenotypic plasticity index for each trait and locality was quantified as the percentage of change in absolute high and low mean trait values, irrespective of salinity treatment; that is, $\mathrm{P}=\left[\left(\mathrm{X}_{\max }-\mathrm{X}_{\min }\right) / \mathrm{X}_{\max }\right] \times 100$, where $\mathrm{P}$ is plasticity, $\mathrm{X}_{\max }$ is the highest mean value for a given trait and $X_{\min }$ is the lowest mean value for a given trait. Traits with negative values (e.g. plant water potential) were evaluated using the absolute value of the negative trait differences, divided by the absolute value of the most negative value. Means represent five replicated measurements per trait for plants from each of four populations in the experiment. To estimate the overall plasticity index for each population, we calculated the arithmetic average of the plasticity index observed for all 21 traits combined for plants from each of the four population sites (MolinaMontenegro and Naya 2012).

\section{Statistical analyses}

Response variables were classified into five functional trait groups for use as dependent variables in the analyses: (1) growth and allocation, (2) leaf morphological traits, (3) photosynthetic traits, (4) Leaf $\mathrm{N}$ and pigment concentrations, and (5) leaf $\mathrm{Na}$ and osmotic solute concentrations. Dependent variables were tested for homogeneity of variances, and transformations were performed on SLA, Na exudation rate, leaf $\mathrm{Na}$, leaf proline, and $\Psi_{\text {leaf }}$ to meet assumptions for parametric analyses. To protect analyses from type I error, we used the protected analysis of variance (ANOVA) protocol (Scheiner 2001), comparing means across population and salinity treatments first with MANOVA and using Pillai's Trace to evaluate significance. When significance was confirmed, we evaluated relevant univariate comparisons (GLM models). All multivariate and univariate GLMs tested the same factors: population (VI, HB, MR, and SF), salinity treatment $(0.5,15$, and $35 \mathrm{ppt})$, population by salinity interaction, and mesocosm nested in salinity treatment, in which mesocosm was considered a random factor. Post-hoc Tukey tests with Bonferronicorrected $\alpha$-levels were performed for each trait when salinity treatment or population site were significant in the univariate ANOVA model. Analyses were performed using SAS V. 9.2 for Windows (SAS Institute Inc., Cary, NC USA).

\section{Results}

Trait responses

All trait response groups were affected by the salinity treatments (MANOVA results, Online Resource 1). Salinity had a significant effect on plant growth and biomass allocation $\left(\mathrm{F}_{6,70}=3.88, \quad p=0.0021\right.$; Fig. 1a-c), leaf morphological traits $\left(\mathrm{F}_{8,68}=7.66\right.$, $p=0.0001$; Fig. 1d-g), instantaneous photosynthetic traits $\left(\mathrm{F}_{12,64}=8.93, p=0.0001\right.$; Fig. 2$)$, leaf nitrogen and pigments $\left(\mathrm{F}_{8,68}=6.69, p=0.0001\right.$; Fig. 3), and leaf chemistry $\left(\mathrm{F}_{8,68}=37.53, p=0.0001\right.$; Fig. 4). Results of subsequent univariate GLM analyses for each of the measured trait responses indicate population was a significant factor in all growth and biomass allocation traits, including shoot mass (SM; $\mathrm{F}_{3,36}=20.71, p=0.0001$; Fig. 1a), root mass (RM; $\mathrm{F}_{3,36}=18.94, p=0.0001$; Fig. $1 \mathrm{~b}$ ), and root mass ratio (RMR; $\mathrm{F}_{3,36}=3.63, p=0.0218$; Fig. $1 \mathrm{c}$ ). Shoot mass and root mass were highest in plants collected from VI as compared to all other populations; shoot mass of VI plants was 3.25 times higher and root mass, 2.6 times higher than the growth measured in plants from MR. Plants in the more saline treatments had higher root mass ratio, although root mass ratio in plants from $\mathrm{HB}$ decreased in the highest salinity treatment $\left(\mathrm{F}_{2,36}=3.35, p=0.0001\right)$. While leaf traits as a composite response group responded significantly to salinity treatments, leaf area was only moderately influenced by soil salinity $\left(\mathrm{F}_{3,36}=2.61\right.$, $p=0.0876$; Online Resource 1). On the other hand, population strongly influenced total leaf area production (LA; $\mathrm{F}_{3,36}=16.99, p=0.0001$; Fig. 1d), where leaf area was 2.3 times higher in plants from the VI population. Specific leaf area was affected by both salinity treatment $\left(\mathrm{SLA} ; \mathrm{F}_{2,36}=4.77, p=0.0145\right)$ and population $\left(\mathrm{F}_{3,36}=6.91, p=0.0009\right)$. Plants collected at MR had slightly higher SLA on average, but all plants in the highest salinity treatments (30 ppt) had up to $25 \%$ lower SLA than plants exposed to 0.5 or 15 ppt salinity treatments (Fig. 1e). Leaf elongation rate did not show a response to salinity treatment, nor population site (Online Resource 1), but population $\left(\mathrm{F}_{3,36}=4.07, \quad p=0.0138 ; \quad\right.$ Fig. $\left.1 \mathrm{f}\right)$ and salinity $\left(\mathrm{F}_{2,36}=103.08, p=0.0001 ;\right.$ Fig. $\left.1 \mathrm{f}\right)$ were important in determining the degree of adaxial leaf rolling.

Salt stimulation of photosynthesis was observed, with photosynthetic responses among treatments fairly 

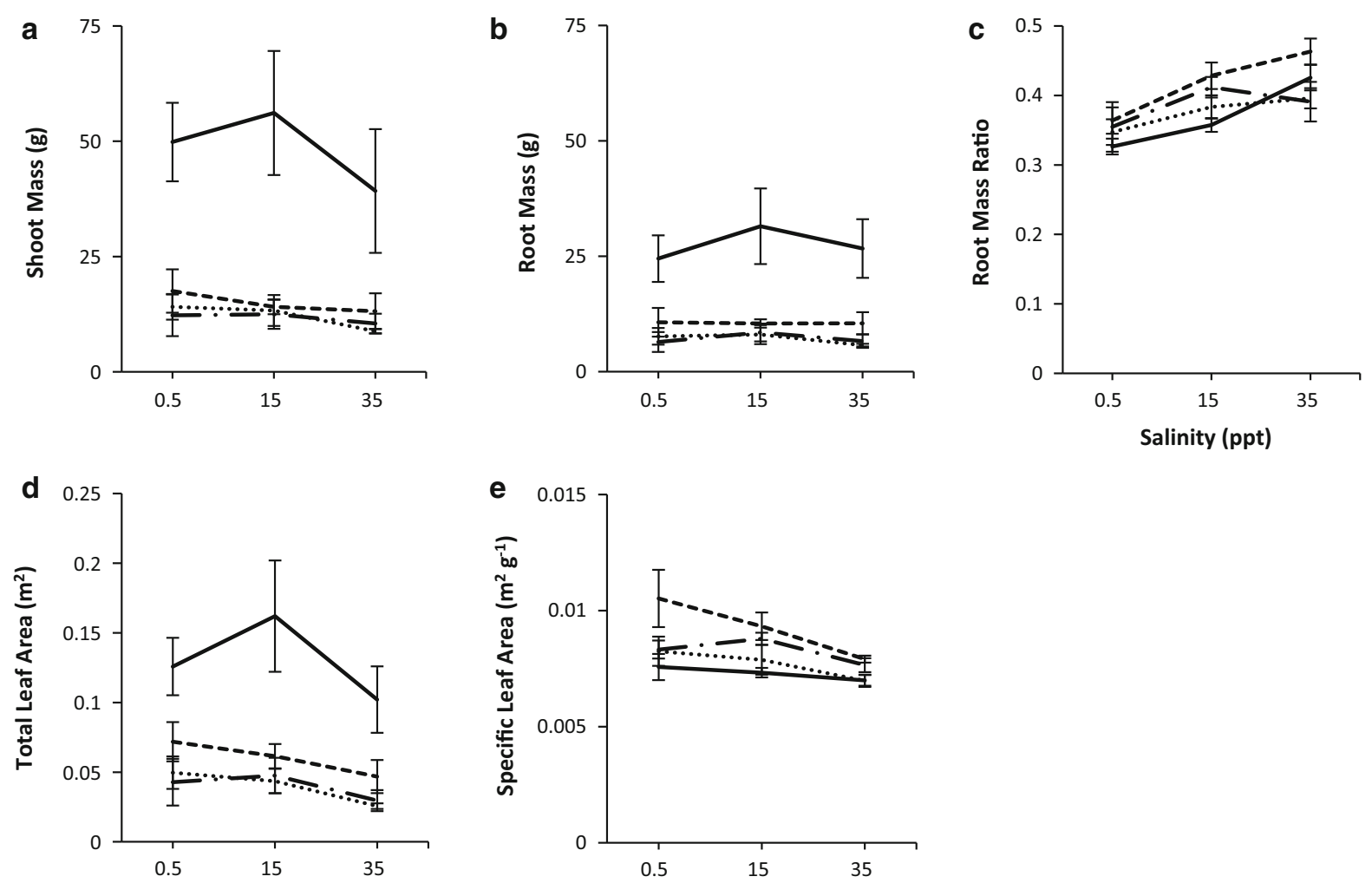

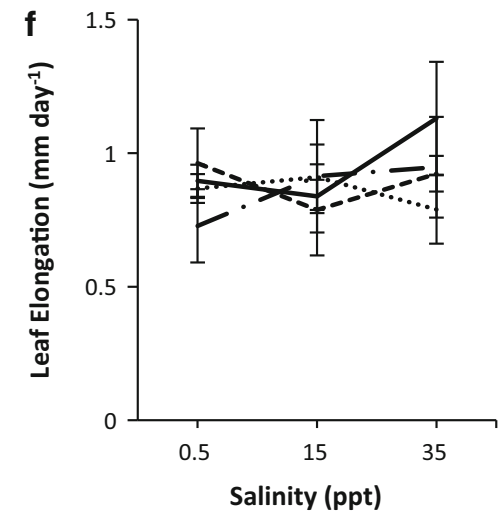

Fig. 1 Reaction norms (mean $\pm \mathrm{SD}$ ) of $S$. densiflora from four estuary populations for growth (biomass and allocation) and leaf trait responses to experimentally imposed salinity treatments. Source populations are San Francisco Estuary, California (SF);

symmetrical and highest gas exchange measured in plants subjected to brackish (15 ppt) salinity (Fig. 2). Both the rate of $\mathrm{CO}_{2}$ assimilation per unit leaf area $\left(\mathrm{A}_{\mathrm{sat}}\right)$ and stomatal conductance $\left(\mathrm{g}_{\mathrm{s}}\right)$ suggest the process of photosynthesis was influenced by population site $\left(\mathrm{A}_{\mathrm{sat}}\right.$ : $\mathrm{F}_{3,36}=3.50, p=0.0250 ; \mathrm{g}_{\mathrm{s}}: \mathrm{F}_{3,36}=2.93, p=0.0467$; Fig. 2a, b), and $g_{s}$ was additionally influenced by salinity treatment $\left(\mathrm{F}_{2,36}=5.61, p=0.0076\right) . \mathrm{A}_{\text {sat }}$ and $\mathrm{g}_{\mathrm{s}}$ were highest in plants collected in VI (Fig. 2a, b), and $g_{s}$ was highest in the 15 ppt salinity treatment (Fig. 2b). Leaf water potential responded strongly to salinity treatment $\left(\mathrm{F}_{2,36}=52.06, p=0.0001\right)$ and was increasingly negative with increased salinity treatments (Fig. 2c). Leaf water potential was more strongly negative in plants 
Fig. 2 Reaction norms (mean $\pm \mathrm{SD}$ ) of $S$. densiflora from four estuary populations for gas exchange and leaf fluorescence responses across experimentally imposed salinity treatments. Source populations are: San Francisco Estuary, California (SF); Humboldt Bay, California (HB); Mad River Estuary, California (MR); and Baynes Sound, British Columbia Canada (VI)
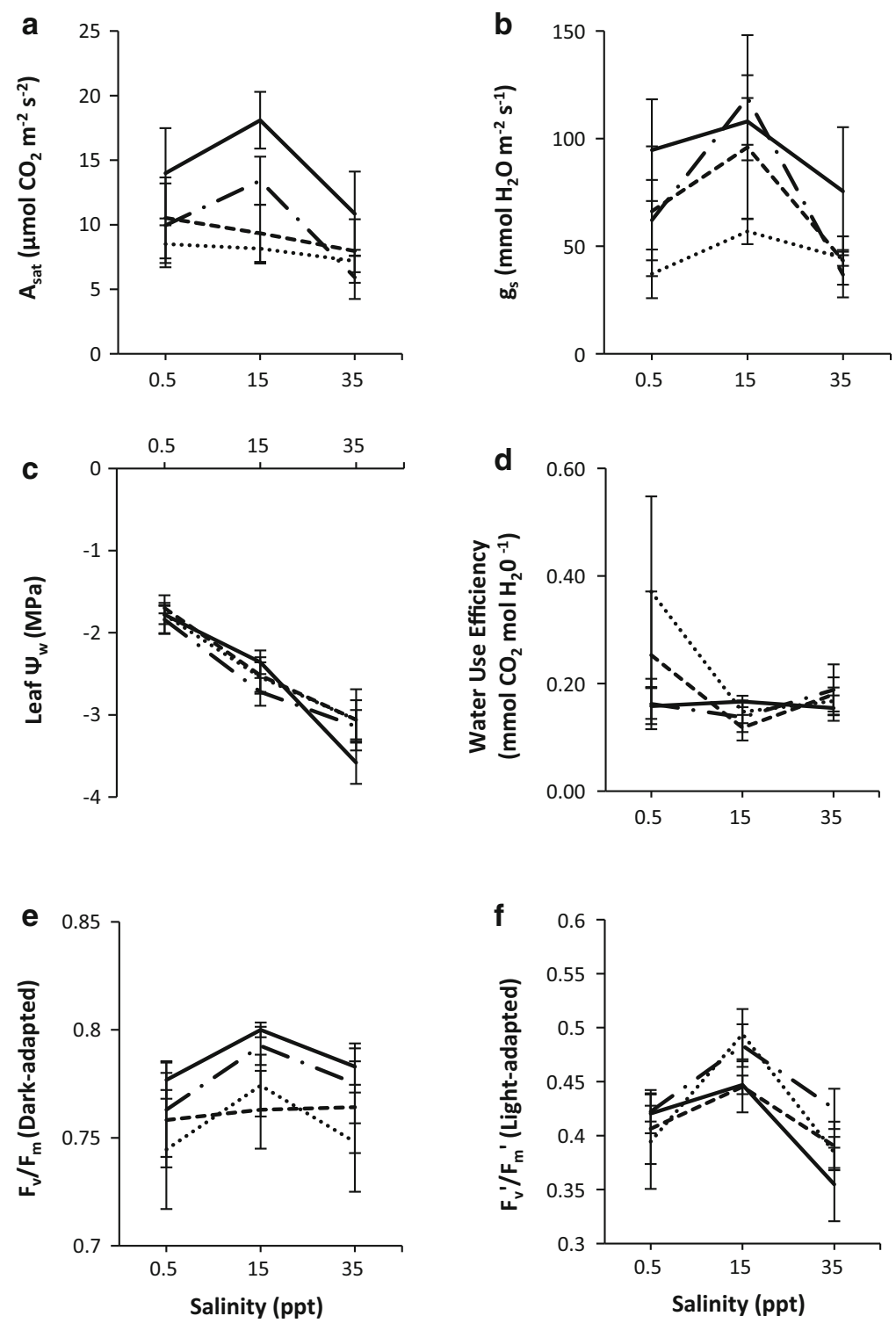

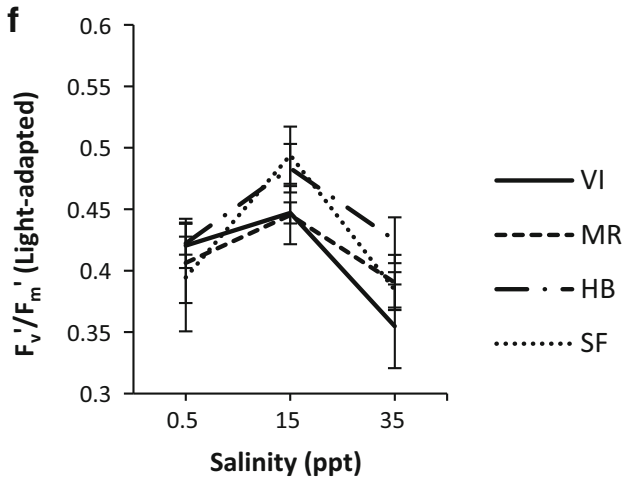

collected from the VI population (WUE; Fig. 4e). Variation among populations in WUE was highest in the freshwater treatments, and although WUE decreased for all plants with increasing salinity level, a salinity effect was not detected at this level of replication (Fig. 2d). Salinity treatment had a significant effect on light-adapted quantum efficiency of PSII $\left(\mathrm{F}_{2,36}=14.20\right.$, $p=0.0001$; Fig. 2f). The quantum efficiency was $20 \%$ higher for plants in the $15 \mathrm{ppt}$ salinity treatment compared to the 35 ppt salinity treatment.

Salinity treatment was a strong driver of leaf $\mathrm{N}$ and associated pigments (Online Resource 1), although the direction of the effect was not consistent for the four traits in this response group. Leaf $\mathrm{N}$ was $20 \%$ lower in the freshwater treatment than the $35 \mathrm{ppt}$ salinity treatment $\left(\mathrm{F}_{2,36}=5.84, p=0.0001\right.$; Fig. 3a). Chlorophyll $a\left(\mathrm{~F}_{2,36}=7.13, \quad p=0.0025\right.$; Fig. $\left.3 \mathrm{~b}\right)$ and $b\left(\mathrm{~F}_{2,36}=13.34, p=0.0001\right.$; Fig. $\left.3 \mathrm{c}\right)$, and carotenoids $\left(\mathrm{F}_{2,36}=6.94, p=0.0028\right.$; Fig. $\left.3 \mathrm{~d}\right)$ all decreased significantly with increasing salinity. Population site was a significant factor in determining chlorophyll pigment concentration (Chl $a: \mathrm{F}_{3,36}=3.75, p=0.0192$; Chl $b$ : $\mathrm{F}_{3,36}=4.03, p=0.0143$; Fig. 3b, c). The interaction between population and salinity was not significant, 
Fig. 3 Reaction norms (mean $\pm \mathrm{SD}$ ) of $S$.

densiflora from four estuary populations for leaf nitrogen and pigment concentrations at three experimentally imposed salinity treatments. Source populations are: San Francisco Estuary, California (SF); Humboldt Bay, California (HB); Mad River Estuary, California (MR); and Baynes Sound, British Columbia Canada (VI)
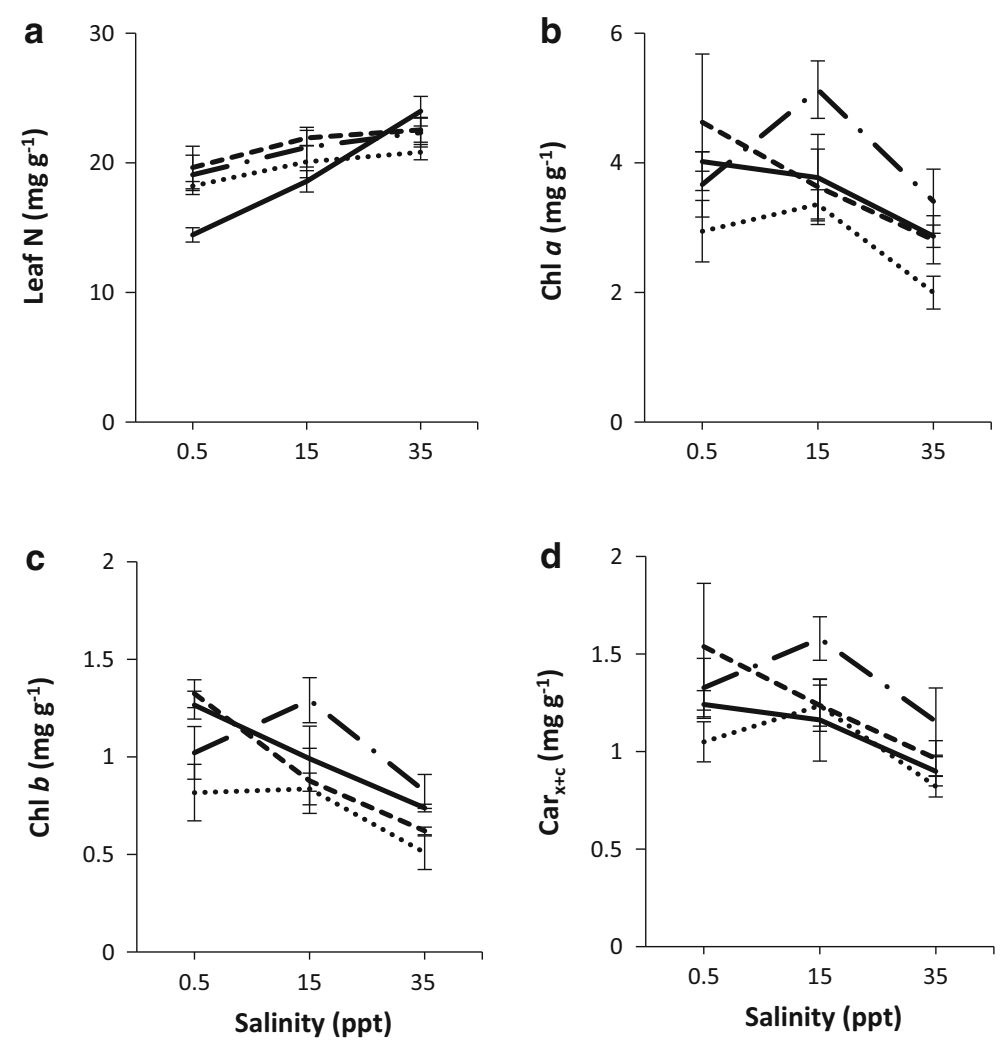

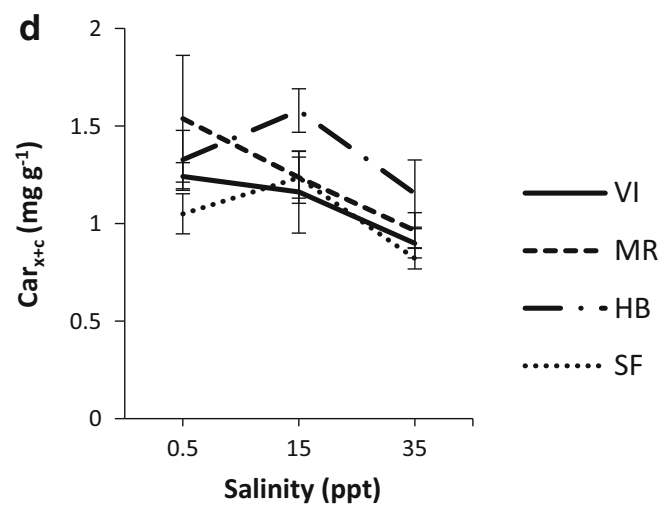

although plants from VI, MR, and SF generally followed a trend of decreasing chlorophyll pigments with increasing salinity. Population was a marginally significant factor for the amount of carotenoids $\left(\mathrm{F}_{3,36}=2.83, p=0.0521\right)$, following the same pattern as described for the amount of chlorophyll (Fig. 3d).

Salinity was also a major determinant of leaf sodium (Na) and related osmotic solutes (Online Resource 1). The significant effect of salinity was consistent, and followed increasing levels of salinity treatment (Fig. 4) for sodium exudation rate $\left(\mathrm{F}_{2,36}=151.55, p=0.0001\right.$; Fig. 4a), leaf $\mathrm{Na}\left(\mathrm{F}_{2,36}=461.26, p=0.001\right.$; Fig. $\left.4 \mathrm{~b}\right)$, proline $\left(\mathrm{F}_{2,36}=173.33, p=0.0001\right.$; Fig. $\left.4 \mathrm{c}\right)$, and glycinebetaine $\left(\mathrm{F}_{2,36}=137.07, p=0.0001\right.$; Fig. $\left.4 \mathrm{~d}\right)$ concentrations. Post-hoc tests showed that sodium exudation was not statistically different between the 15 and 35 ppt salinity treatments.

\section{Trait plasticity}

When averaged across all traits, plasticity indices did not differ among populations (Online Resource 1; Fig. 5a). However, most individual plant traits and each plant trait group exhibited some degree of plasticity in response to salinity or source population, varying from weak to strong expression (Fig. 5b). In general, leaf chemistry traits were most plastic, instantaneous physiological traits and leaf $\mathrm{N}$ and pigments were moderately plastic, and growth and allocation traits were least plastic. Plasticity of leaf traits associated with morphology and growth were highly variable among traits, with adaxial leaf rolling being highly plastic and SLA and leaf elongation rates being relatively non-plastic. Comparing within trait groups, degree of plasticity was consistent (Fig. 5b). The two exceptions to this pattern are found in leaf morphological traits and instantaneous physiological traits. Among leaf morphological traits, adaxial leaf rolling stood out as a particularly plastic trait. Among the instantaneous physiological traits, fluorescence measures of PSII efficiency were much less plastic than the three other measures.

\section{Discussion}

Our experiment and results of companion studies (Castillo et al. 2014, 2015) suggest that individual 
Fig. 4 Reaction norms (mean $\pm \mathrm{SD}$ ) of $S$. densiflora from four estuary populations for leaf chemical stress responses [sodium $(\mathrm{Na})$ and compatible solute concentrations] at three experimentally imposed salinity treatments. Source populations are: San Francisco Estuary, California (SF); Humboldt Bay, California (HB); Mad River Estuary, California (MR); and Baynes Sound, British Columbia Canada (VI)
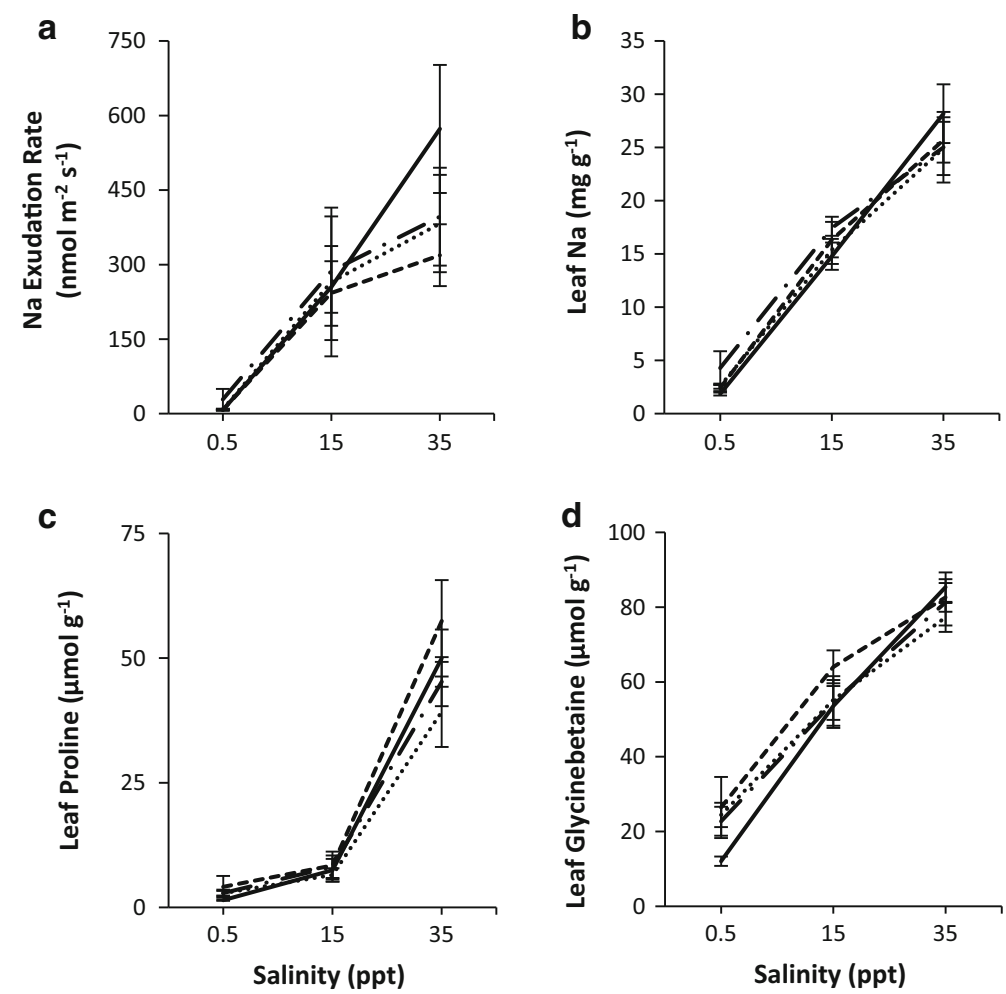

foliar traits and tussock architecture of invasive $S$. densiflora are phenotypically plastic in response to a significant salinity gradient from freshwater to marine concentrations, though growth will be optimal in the brackish range along the invaded Pacific coast of North America. For some of these traits, plasticity was related to population identity. Acclimation to higher salt concentrations occurs through a suite of interacting morphological, physiological and leaf chemistry responses to maintain growth and fitness. Phenotypic plasticity can be an important mechanism that increases invasiveness of species and contributes to the success of biological invasions across habitat conditions by enhancing niche breadth and fitness advantages of invasive plant species (Richards et al. 2006).

Averaged across all traits, populations in our study did not differ in their plasticity responses to the experimentally imposed salinity gradients. However, at the level of individual traits there was evidence for phenotypic plasticity in response to both salinity and population. In general, traits related to growth, allocation, and morphology tended to show low trait plasticity whereas leaf traits associated with instantaneous physiological functions, pigments, and chemistry showed higher plasticity in response to salinity. Some degree of differentiation in absolute trait responses was observed among populations largely due to greater growth of VI plants relative to all other populations. Despite this large difference in growth in one population, biomass allocation patterns between roots and shoots were similar across all populations, with increased root allocation in response to salinity.

Plastic patterns of biomass allocation may ensure more successful foraging for resources with changing environmental conditions and can thereby contribute to the invasion success of plant species (Ruprecht et al. 2014). Evidence from a glasshouse experiment (Kittelson and Boyd 1997), and from field observations in the native range (Di Bella et al. 2014) suggest $S$. densiflora populations can maintain lateral expansion through belowground growth under a wide range of salinity levels. Our experimental results revealed greater allocation to belowground biomass in response to higher salinity (Fig. 1b, c). This favorable allocation response may facilitate rhizomatous expansion towards new resource patches to support and sustain 

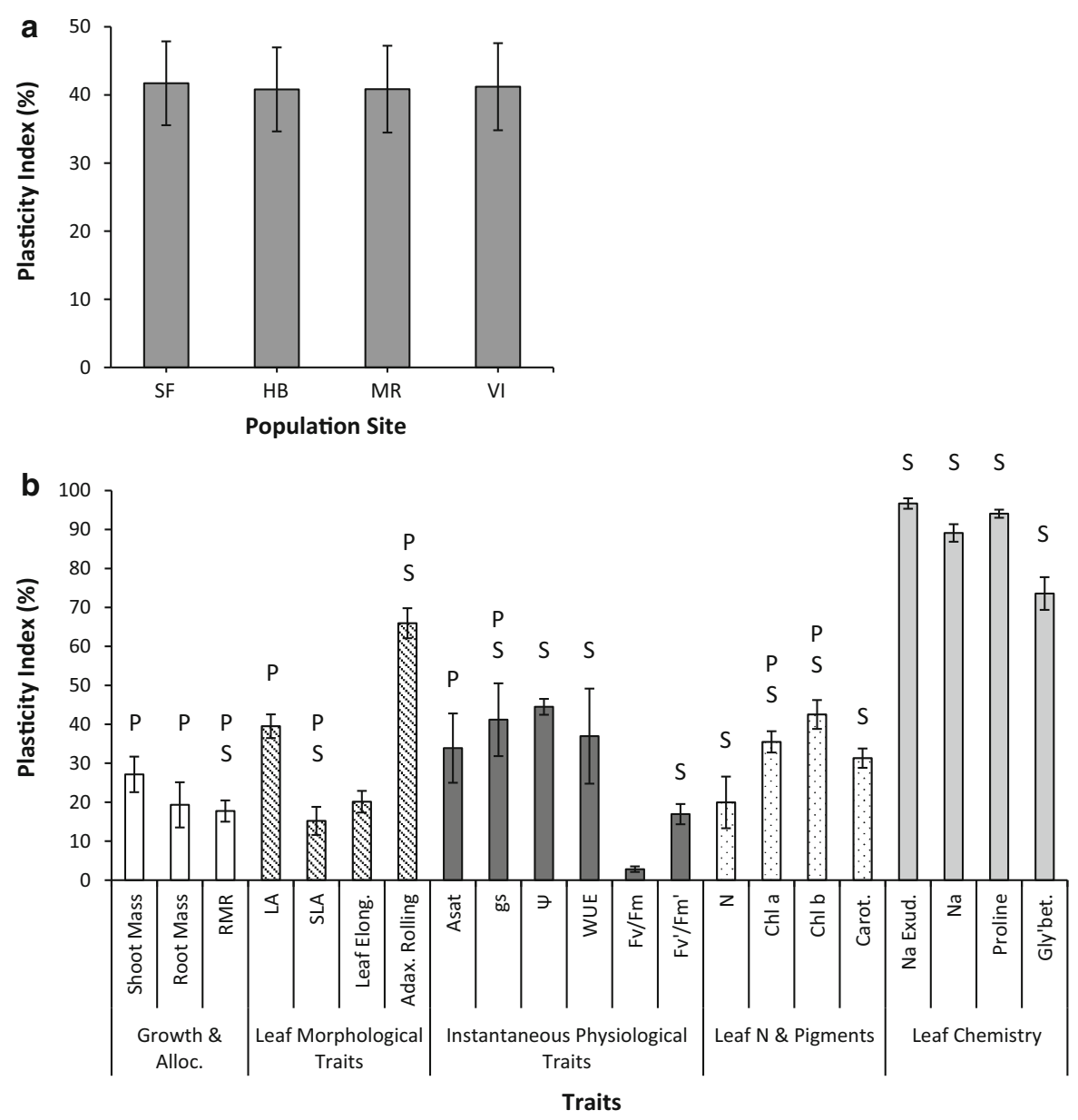

Fig. 5 Plasticity Index (percentage) calculated from a minimum and maximum values from trait means for each of four $S$. densiflora populations ( $\pm \mathrm{SE}, \mathrm{n}=23$; Online Resource 1$)$; and b mean $( \pm \mathrm{SE}, \mathrm{n}=4)$ percent plasticity index $(\mathrm{PPI})$ for traits responding to salinity treatment, using minimum and maximum mean trait values, organized into trait response groups. Letters

clonal growth under stressful, spatially-heterogeneous environmental conditions.

The ability of $S$. densiflora to adjust, maintain and increase leaf $\mathrm{N}$ with rising salinity may reflect effective or high nutrient uptake that can support invasiveness in salt marshes, which are recognized typically as nitrogen-limited systems (Valiela and Teal 1974; Adams 1993). We did not observe suppressed/reduced leaf $\mathrm{N}$ concentration with increasing salinity (Fig. 3a), although competition between toxic $\mathrm{Na}^{+}$and $\mathrm{Cl}^{-}$ions and nutrient $\mathrm{NH}_{4}{ }^{+}$and $\mathrm{NO}_{3}{ }^{-}$ ions would be expected at the root surface due to similarity in size and charge (Marschner 2012). above the bars for each trait denote significant effects of salinity (S) and/or population (P) on the trait response. Source populations are: San Francisco Estuary, California (SF); Humboldt Bay, California (HB); Mad River Estuary, California (MR); and Baynes Sound, British Columbia Canada (VI)

Continued uptake supports synthesis of low molecular weight compatible solutes, such as the increase in concentrations of glycinebetaine and proline we measured with elevated salinity, and which help maintain favorable cellular water relations under increasingly saline conditions. In addition to serving as a compatible osmolyte, the accumulation of proline with salinity stress can protect plant cells from damage and degrade to supply energy to drive readjustments of plant growth in response to abiotic stress; additionally, proline homeostasis supports cell division for maintenance of sustainable growth under long-term stress (Kavi Kishor and Sreenivasulu 2014). 
Recognizing differences in the biology, ecology and evolution among individuals and populations of the same species is necessary to better understand the context of invasion and species expansion (Fortune et al. 2008). Population differences noted in our results suggest some degree of local adaptation may have occurred, though further research is needed to determine if a fitness advantage is achieved. For example, leaf area, shoot, root and total biomass of plants from our highest latitude population site (Fig. 1; VI, $49^{\circ} 33^{\prime \prime} \mathrm{N}$ ) exceeded that of all other populations at all salinity levels, suggesting it may be more invasive than the other sampled populations. In northern latitudes, a shortened growing season with long photoperiods selects for rapid spring growth, supported by large belowground storage reserves (Olsson and Ågren 2002; D'Hertefeldt et al. 2014). In clonal plants, physiological integration improves resource sharing among ramets and generally increases with environmental stress; these traits may enhance the success of invasive plant species (Song et al. 2013). In S. densiflora, physiological integration and the storage capacity of its roots and rhizomes may explain the high biomass production we observed by our VI population under field conditions (D'Hertefeldt et al. 2014). Likewise, we also observed these biomass differences under controlled photoperiods in the glasshouse, suggesting there may be genetic differentiation in physiological integration and biomass production in the northern invasive range of $S$. densiflora that merits further investigation. Predicted salinity increases expected with sea level rise could intensify the selective pressure on these populations across their invaded range, amplifying potential population-level differentiation. Increased selection pressure on salinity response traits along with other interacting environmental conditions has important management implications (e.g. modeling future range expansions, spatial prioritization of management actions), emphasizing the importance of recognizing potential genetic differences among populations.

Polyploidy and higher chromosome numbers in vascular plants can contribute to increased invasiveness through increases in phenotypic variation and stress tolerance, which can create a positive feedback loop supporting further evolution of invasiveness (Ainouche and Jenczewski 2010; te Beest et al. 2012; Pandit et al. 2014). Polyploidy has been a driving force behind speciation in the genus Spartina
(Ainouche et al. 2004), and alloheptaploid S. densiflora in our study populations has a polyphyletic origin composed of divergent genomes that have undergone reticulate evolution (Fortune et al. 2008). Therefore, the high degree of plasticity in response to salinity that we observed for some traits is not unexpected. $S$. densiflora has higher chromosome numbers and ploidy level than native and other invasive, non-native Spartina species with the exception of invasive dodecaploid Spartina anglica $(2 \mathrm{n}=120-124)$, which has invaded several continents and rapidly spread among salt marshes in western Europe (Thompson 1991; Ainouche et al. 2009) and a few locations in California and Washington. Phenotypic plasticity in $S$. anglica is believed to explain its spread and persistence in varying environments (Thompson 1991). In general, the predicted spread of Spartina species with high ploidy levels and their capacity for phenotypic variation are of great concern in the context of climate change (Loebl et al. 2006). Our observations of $S$. densiflora would support these predictions. As observed in other halophytes, S. densiflora uses a combination morphological and biochemical mechanisms to counter salt stress and maintain osmotic potential as salinity increases in the root environment (Duarte et al. 2014).

Climate change predictions include increases in extreme precipitation events that could provide short term decreases in salinity within invaded wetlands. In this case, our results suggest $S$. densiflora should also acclimate to these changing conditions given the flexibility of its foliar traits. However, across multiple traits, plant responses were most robust under brackish conditions, and optimal growth occurred under brackish salinity. Similarly, Castillo et al. (2005) reported that $S$. densiflora showed suboptimal functioning of the photosynthetic apparatus in fresh water in the short-term. Despite these observations, $S$. densiflora is not an obligate halophyte (as defined by Barbour 1970), since it can complete its life cycle in fresh water conditions. Additionally, salinity responses may depend on life stage. For example, seed germination and seedling growth and survivorship are optimal in fresh to low salinity water and limited at higher salinities (Kittelson and Boyd 1997). Thus, sexual recruitment may be a less viable reproductive mode as salinity increases with sea level rise.

As sea level rises, increased inundation and salinity is expected to promote conversion of brackish marshes 
to salt marshes, and intrusion of brackish waters into upstream areas of drowned river estuaries that are currently fresh (Parker et al. 2011). This conversion of coastal wetlands should favor $S$. densiflora, although glycophytes can competitively exclude $S$. densiflora seedling establishment under low salinity (Abbas et al. 2015). Established S. densiflora may be highly competitive under higher salinity due its plasticity and stress tolerance and will likely shift position and spread upstream as salinity rises in drowned river estuaries, although we expect plant performance will vary depending on the interaction of salinity with inundation levels and other changing environmental factors. Understanding potential niche breadth via plasticity or adaptation may help improve assessments of invasion risk and management strategies in this time of rapid climate change.

Acknowledgments We thank A. Pickart for encouraging this research. We thank C.J. Futrell who contributed to propagation and maintenance of plant cultures, participated in measurement of plant response traits, and performed chemical analyses of plant tissue. Kevin Rice provided a pressure bomb instrument and comments that improved the manuscript. A. Pickart and A. Bortulus participated in field collection of plant material, and A. Pickart and M. Sytsma provided logistical support.

\section{References}

Abbas AM, Lambert AM, Rubio-Casal AE, de Cires A, Figueroa E, Castillo JM (2015) Competition from native hydrophytes reduces establishment and growth of invasive dense-flowered cordgrass (Spartina densiflora). PeerJ 3:e1260. doi:10.7717/peerj.1260

Adam P (1993) Saltmarsh ecology. Cambridge University Press, Cambridge

Ainouche ML, Jenczewski E (2010) Focus on polyploidy. New Phytol 186:1-4

Ainouche ML, Baumel A, Salmon A (2004) Spartina anglica C. E. Hubbard: a natural model system for analysing early evolutionary changes that affect allopolyploid genomes. Biol J Linn Soc 82:475-484

Ainouche ML, Fortune M, Salmon A et al (2009) Hybridization, polyploidy and invasion: lessons from Spartina (Poaceae). Biol Invasions 11:1159-1173

Ainouche ML, Chelaifa J, Ferreira S, Bellot A, Ainouche A, Salmon A (2012) Polyploid evolution in Spartina: dealing with highly redundant hybrid genomes. In: Soltis PS, Soltis DE (eds) Polyploidy and genome evolution. Springer, Berlin, pp 225-243

Ayres DR, Smith DL, Zaremba K, Klohr S, Strong DR (2004) Spread of exotic cordgrasses and hybrids (Spartina sp.) in the tidal marshes of San-Francisco Bay, CA, USA. Biol Invasions 6:221-231
Ayres DR, Grotkopp EK, Zaremba K et al (2008) Hybridization between invasive Spartina densiflora (Poaceae) and native S. foliosa in San Francisco Bay, California, USA. Am J Bot 95:713-719

Barbour MG (1970) Is any angiosperm an obligate halophyte? Am Midl Nat 84:105-120

Bates LS, Waldren RP, Teare JD (1973) Rapid determination of free proline for water stress studies. Plant Soil 39:205-207

Bertness MD (1991) Zonation of Spartina patens and Spartina alterniflora in a New England salt marsh. Ecology 72:138-148

Bortolus A (2006) The austral cordgrass Spartina densiflora Brong.: its taxonomy, biogeography and natural history. J Biogeogr 33:158-168

Callaway JC, Borde AB, Diefenderfer HL, Parker VT, Rybczyk JM, Thom RM (2012) Pacific coast tidal wetlands. In: Batzer DB, Baldwin AH (eds) Wetland habitats of North America: ecology and conservation concerns. University of California Press, Berkeley, pp 103-116

Caño L, Escarré J, Fleck I, Blanco-Moreno JM, Sans FX (2008) Increased fitness and plasticity of an invasive species in its introduced range: a study using Senecio pterophorus. J Ecol 96:468-476

Castillo JM, Rubio-Casal AE, Redondo S, Antonio A, AlvarezLopez A, Luque T, Luque C, Nieva FJ, Castellanos EM, Figueroa ME (2005) Short term responses to salinity of an invasive cordgrass. Biol Invasions 7:29-35

Castillo JM, Ayres DR, Leira-Doce P, Bailey J, Blum M et al (2010) The production of hydrids with high ecological amplitude between exotic Spartina densiflora and native $S$. maritima in the Iberian Peninsula. Divers Distrib 16:547-558

Castillo JM, Grewell BJ, Pickart A, Bortolus A, Peña C, Figueroa E, Sytsma M (2014) Phenotypic plasticity of invasive Spartina densiflora (Poaceae) along the Pacific Coast of North America. Am J Bot 101:1-11

Castillo JM, Grewell BJ, Pickart AJ, Figueroa E, Sytsma M (2015) Variation in tussock architecture of the invasive cordgrass Spartina densiflora along the Pacific Coast of North America. Biol Invasions. doi:10.1007/s10530-0150991-3

Christman MA, James JJ, Drenovsky RE, Richards JH (2009) Environmental stress and genetics influence night-time leaf conductance in the $\mathrm{C}_{4}$ grass Distichlis spicata. Funct Plant Biol 36:50-55

D'Hertefeldt TD, Eneström JM, Pettresson LB (2014) Geographic and habitat origin influence biomass production and storage translocation in the clonal plant Aegopodium podagraria. PLoS ONE 9:1-8

Di Bella CE, Striker GG, Escaray FJ, Lattanzi FA, Rodriguez AM, Grimaldi AA (2014) Saline tidal flooding effects on Spartina densiflora plants from different positions in the salt marsh. Diversities and similarities on growth, anatomical and physiological responses. Environ Exp Bot 102:27-36

Dlugosch KM, Parker IM (2008) Invading populations of an ornamental shrub show rapid life history evolution despite genetic bottlenecks. Ecol Lett 11:701-709

Drenovsky RD, Grewell BJ, D’Antonio CM, Funk JL, James JJ, Molinari N, Parker IM, Richards CL (2012) A functional trait perspective on plant invasion. Ann Bot Lond 110:141-153 
Duarte B, Sleimi N, Caçador I (2014) Biophysical and biochemical constraints imposed by salt stress: learning from halophytes. Front Plant Sci 5:1-10

Dukes JS, Mooney HA (1999) Does global change increase the success of plant invaders? Trends Ecol Evol 14:135-139

Faber P (2000) Grass wars: good intentions gone awry: Why would anyone bring an alien cordgrass into San Francisco Bay? Calif Coast Ocean 16:14-17

Fortune PM, Schierenbeck K, Ayres D, Bortolus A, Catrice O, Brown S, Ainouche ML (2008) The enigmatic invasive Spartina densiflora: a history of hybridizations in a polyploidy context. Mol Ecol 17:4304-4316

Grieve CM, Grattan SR (1983) Rapid assay for determination of water soluble quaternary ammonium compounds. Plant Soil 70:303-307

Hester MW, Mendelssohn IA, McKee KL (2001) Species and population variation to salinity stress in Panicum, Spartina patens and Spartina alterniflora: morphological and physiological constraints. Environ Exp Bot 46:277-297

Howard R, Mendelssohn IA (1999) Salinity as a constraint on growth of oligohaline marsh macrophytes. I. Species variation in stress tolerance. Am J Bot 86:785-794

Kavi Kishor PB, Sreenivasulu N (2014) Is proline accumulation per se correlated with stress tolerance or is proline homeostasis a more critical issue? Plant Cell Environ 37:300-311

Kittelson PM, Boyd MJ (1997) Mechanism of expansion for an introduced species of cordgrass, Spartina densiflora, in Humboldt Bay, California. Estuaries 20:770-778

Leger EA, Rice KJ (2003) Invasive California poppies (Eschscholzia californica Cham.) grow larger than native individuals under reduced competition. Ecol Lett 6:257-264

Loebl M, van Beusekom JEE, Reise K (2006) Is spread of the neophyte Spartina anglica recently enhanced by increasing temperatures? Aquat Ecol 40:315-324

Maron JL, Vila M, Bommarco R, Elmendorf S, Beardsley P (2004) Rapid evolution of an invasive plant. Ecol Monogr 74:261-280

Marschner H (2012) Mineral nutrition of higher plants, 3rd edn. Academic Press, London

Molina-Montenegro MA, Naya DE (2012) Latitudinal patterns in phenotypic plasticity and fitness-related traits: assessing the climatic variability hypothesis $(\mathrm{CVH})$ with an invasive plant species. PLoS ONE 7(10):e47620. doi:10.1371/ journal.pone.004762

Nieva FJ, Diaz-Espejo A, Castellanos EM, Figueroa ME (2001) Field variability of invading populations of Spartina densiflora Brong. grown in different habitats of the Odiel marshes (SW Spain). Estuar Coast Shelf Sci 52:515-527

Nieva FJ, Castellanos EM, Castillo JM, Figueroa ME (2005) Clonal growth and tiller demography of the invader cordgrass Spartina densiflora Brongn. at two contrasting habitats in SW European salt marshes. Wetlands 25:122-129

Olsson K, Ågren J (2002) Latitudinal population differentiation in phenology, life history and flower morphology in the perennial herb Lythrum salicaria. J Evol Biol 15:983-996

Pandit MK, White SM, Pocock MJO (2014) The contrasting effects of genome size, chromosome number and ploidy level on plant invasiveness: a global analysis. New Phytol 203:697-703

Parker VT, Callaway JC, Schile LM, Vasey MC, Herbert ER (2011) Climate change and San Francisco Bay-Delta tidal wetlands. San Franc Estuary Watershed Sci 9:1-15. Retrieved from: http://www.escholarship.org/uc/item/ 8j20685w

Perazzolo M, Pinheiro F (1991) Aspectos anatómicos e adaptativos das partes vegetativas de Spartina densiflora Brong. (Gramineae) da marisma do estuário da lagoa dos PatosRS. Acta Bot Bras 5:3-16

Richards CL (2012) Epigenetics: linking genotype and phenotype in development and evolution. Integr Comp Biol 52:547-549

Richards CL, Bossdorf O, Muth NZ, Gurevitch J, Pigliucci M (2006) Jack of all trades, master of some? On the role of phenotypic plasticity in plant invasions. Ecol Lett 9:981-993

Ruprecht E, Fenesi A, Nijs N (2014) Are plasticity in functional traits and constancy in performance traits linked with invasiveness? An experimental test comparing invasive and naturalized plant species. Biol Invasions 16:13591372

Scheiner SM (2001) MANOVA: multiple response variables and multi-species interactions. In: Scheiner SM, Gurevitch J (eds) Design and analysis of ecological experiments, 2nd edn. Oxford University Press, Oxford, pp 99-115

Shumway SW, Bertness MD (1994) Patch size effects on marsh secondary succession mechanisms. Ecology 75:564-568

Song YB, Yu FH, Keser L et al (2013) United we stand, divided we fall: a meta-analysis of experiments on clonal integration and its relationship to invasiveness. Oecologia 171:317-327

Spicher D, Josselyn M (1985) Spartina (Gramineae) in northern California: distribution and taxonomic notes. Madroño 32:158-167

Strong DR, Ayres DR (2013) Ecological and evolutionary misadventures of Spartina. Annu Rev Ecol Evol Syst 44:389-410

te Beest M, Le Roux JJ, Richardson DM, Brysting AK, Kubesová M, Pysek P (2012) The more the better? The role of polyploidy in facilitating plant invasions. Ann Bot Lond 109:19-45

Thompson JD (1991) The biology of an invasive plant. What makes Spartina anglica so successful? Bioscience 41:393-401

Valiela I, Teal JM (1974) Nutrient limitation of salt marsh vegetation. In: Reimold RJ, Queen WH (eds) Ecology of halophytes. Academic Press, New York, pp 547-563

Valladares F, Sanchez-Gomez D, Zavala MA (2006) Quantitative estimation of phenotypic plasticity: bridging the gap between the evolutionary concept and its ecological applications. J Ecol 94:1103-1116

Vilà M, Corbin JD, Ducks JS, Pino J, Smith SD (2007) Linking plant invasions to global change. In: Canadell J, Pataki D, Pitelka L (eds) Terrestrial ecosystems in a changing world. Springer, New York, pp 93-102 